ORIGINAL PAPER

\title{
The relationship of TP5 3 and GRIN2B GeNe POLYMORPHISMS WITH RISK OF OCCURRENCE AND PROGRESSION OF PRIMARY OPEN-ANgle glaucoma in a Polish population
}

\author{
Alicja Nowak ${ }^{1}$, Karolina Przybylowska-Sygut ${ }^{1}$, Katarzyna Szymanek ${ }^{2}$, Jerzy Szaflik ${ }^{2}$, \\ Jacek P. Szaflik ${ }^{2}$, Ireneusz Majsterek ${ }^{1}$
}

\begin{abstract}
${ }^{1}$ Department of Clinical Chemistry and Biochemistry, Medical University of Lodz, Lodz, Poland ${ }^{2}$ Department of Ophthalmology, Medical University of Warsaw, Warsaw, Poland, SPKSO University Ophthalmic Hospital, Warsaw, Poland
\end{abstract}

\begin{abstract}
Introduction: Glaucoma is characterized by optic neuropathy of the retinal ganglion cells (RGCs). Retinal ganglian cell death may be mediated by apoptosis. TP53 is involved in this process. It can also be found that excitotoxicity contributes to apoptosis by excess stimulation of glutamate receptors. The aim of this study was to evaluate the relationship of the TP53 (rs1042522) and GRIN2B (rs3764028) gene polymorphisms with risk of occurrence of primary open-angle glaucoma (POAG). Material and methods: The study population consisted of 186 patients and 188 healthy subjects. Genomic DNA was extracted from peripheral blood. Analysis of the gene polymorphisms was performed using PCR-RFLP.

Results: Comparison of the distributions of genotypes and alleles of the rs 1042522 and rs3764028 polymorphisms showed no statistically significant differences between POAG patients and controls $(\mathrm{p}>0.05)$. There was a statistically significant association of the rs 1042522 polymorphism with progression of POAG depending on the retinal nerve fiber layer $(\mathrm{p}=0.019)$. However, no significant differences between rs3764028 polymorphism and clinical parameters of POAG were observed $(\mathrm{p}>0.05)$.

Conclusions: The TP53 Arg72Pro and GRIN2B -421C/A gene polymorphisms were not associated with risk of occurrence of POAG in the Polish population. However, the Arg72Pro polymorphism of the TP53 gene may be related to progression of POAG.
\end{abstract}

Key words: glaucoma, neurodegeneration, gene polymorphism, apoptosis, excitotoxicity.

\section{Introduction}

Glaucoma is one of the leading causes of vision loss in the world, especially among the elderly [1]. It is estimated that over 70 million people are affected by glaucoma worldwide, while in Poland the number is as high as 700 thousand patients. Moreover, it is anticipated that in 2020 the number of patients will increase to 79 million and of these $74 \%$ will have primary open-angle glaucoma (POAG), the most common type of glaucoma $[2,3]$.

Glaucoma is a chronic neurodegenerative disease characterized by retinal ganglion cell (RGC) death, axon loss and an excavated appearance to the optic nerve head [4]. One of the main risk factors of glaucoma is elevated intraocular pressure (IOP) (nor- 
mal range: 11-21 $\mathrm{mmHg}$ ). However, in some patients with glaucoma, IOP is within normal limits [5]. Therefore, there must be an IOP-independent mechanism responsible for cell death of RGCs. Several studies have demonstrated that RGCs die during development and as a result of a variety of optic nerve diseases by programmed cell death or apoptosis [6-8]. Specific factors contribute to apoptosis in glaucoma, including blockage of axonal transport [9], glutamate excitotoxicity [10], antibodies to heat shock proteins [11], ischemia [12], and vasoactive regulators such as endothelin [13].

Apoptosis is a genetically controlled form of cell death. It is associated with characteristic changes in cell morphology. These changes include decrease of cytoplasmic and nuclear volumes, degradation of nuclear DNA by endonucleases which causes condensation of chromatin and blebbing of plasma membrane [14]. Numerous studies have shown that RGC death takes place by apoptosis. Mittag et al. demonstrated that rat eyes after 4 months of IOP elevation displayed reduction of mitochondrial membrane potential and DNA fragmentation of RGCs [15]. Kerrigan et al. using the TUNEL assay detected internucleosomal DNA fragmentation in human retinas with glaucoma compared to age-matched control retinas without any changes [16]. These studies directly indicate a role for apoptosis in RGC death in glaucoma.

Apoptosis is controlled by specific genes and their products that are activated by the dying cell. One of the most important regulators of apoptotic proteins is the tumor suppressor protein TP53. In response to various cellular stresses TP53 regulates the cell cycle, apoptosis, senescence and DNA repair. TP53 acts as a transcription factor that can upregulate the expression of the pro-apoptotic gene $B A X$ and downregulate the expression of the anti-apoptotic gene $B C L-2$. The quantitative changes of these gene products may lead to the initiation of apoptosis [17]. The study of an experimental model of glaucoma showed that TP53 is overexpressed in retinal ganglion cells compared to healthy subjects [18]. Moreover, the expression of TP53 is observed in RGCs under conditions that would stimulate apoptosis $[19,20]$. Polymorphic variants in the TP53 gene can lead to changes in apoptotic activity of TP53. TP53 gene polymorphism at codon 72 (rs1042522) is associated with alteration of the amino acid residue from Arg to Pro $(\mathrm{G} \rightarrow \mathrm{C}$ substitution). This polymorphism is located in the proline-rich PXXP domain, which is necessary for the protein to fully induce apoptosis [21]. Polymorphic variants of Arg/Pro significantly affect the biological activity of TP53. The variant TP53-Pro has increased apoptotic activity in cancer cells in hypoxic conditions, whereas the variant TP53-Arg showed this property in human osteosarcoma cell lines [22, 23]. Nevertheless, the apoptotic activity of this polymorphism in RGCs is not yet understood. Previous studies have reported that the TP53 codon 72 polymorphism is associated with POAG [24-26], but other research has not confirmed these results $[27,28]$. These inconsistent data necessitate more studies with a larger number of cases and different ethnic populations to fully elucidate the relationship between TP53 and POAG.

One of the mechanisms leading to apoptosis of RGCs is excitotoxicity [10]. This process describes neuronal injury by excess stimulation of amino acid receptors, including glutamate receptors. The $N$-methyl$\mathrm{d}$-aspartate (NMDA) receptor is a subtype of ionotropic glutamate receptors in postsynaptic membrane. Physiologically, the function of NMDA receptors as highly permeable $\mathrm{Ca}^{2+}$ channels by binding glutamate is pivotal for synaptic plasticity and long-term potentiation (LTP) [29]. Excessive stimulation of the NMDA receptor leads to excessive intracellular $\mathrm{Ca}^{2+}$ influx, generation of free radicals such as nitric oxide and reactive oxygen species, collapse of the mitochondrial membrane potential, loss of ATP, and consequently apoptosis [30]. Five subunits of NMDA receptor have been described: NR1, NR2A-NR2D [31]. An immunohistochemical study showed that NMDA receptor subunits are located on the inner retina of rodents, particularly at the RGCs [32]. Dreyer et al. demonstrated that glutamate levels in the vitreous were increased in both experimental and clinical glaucoma [10]. Also, studies with NMDA receptor antagonists have shown that the loss of RGCs is attenuated in rodent and primate models of chronically elevated IOP $[33,34]$ and after optic nerve crush injury in rodents [35]. The NR2B subunit is one of the most important functional subunits of the NMDA receptor, because it is a glutamate-binding site [36]. Zhao et al. showed that the NR2B subunit of the NMDA receptor participates in both LTP and contextual memory in the prefrontal cortex [37]. Therefore, polymorphic variants of the NR2B subunit gene (GRIN2B) may be associated with the development of neurodegenerative diseases, including glaucoma. Jiang et al. demonstrated the relationship between $-421 \mathrm{C} / \mathrm{A}$ polymorphism (rs3764028) of the GRIN2B gene and the development of Alzheimer's disease [38].

These data prompted us to evaluate the relationship between single nucleotide polymorphisms (SNPs) of the TP53 and GRIN2B genes and risk of occurrence of primary open-angle glaucoma in a Polish population.

\section{Material and methods}

\section{Study subjects}

In the present study we investigated a total of 374 unrelated Caucasian subjects (Table I). Among them 186 subjects had POAG (71 males and 115 females; mean age $73 \pm 10)$ and 188 subjects were a control 
Table I. Clinical parameters characteristic of POAG patients and control group

\begin{tabular}{|c|c|c|c|}
\hline & PARAMETERS & Patient group & CONTROL GROUP \\
\hline \multirow[t]{6}{*}{ Number } & Gender & $71 / 115$ & $98 / 90$ \\
\hline & male/female & $(38 \% / 62 \%)$ & $(52 \% / 48 \%)$ \\
\hline & Hypertension* & $100(54 \%)$ & $132(70 \%)$ \\
\hline & Low blood pressure $* *$ & $74(40 \%)$ & $54(29 \%)$ \\
\hline & Vascular disease & $61(33 \%)$ & $92(49 \%)$ \\
\hline & Diabetes mellitus type 2 & $32(17 \%)$ & $104(55 \%)$ \\
\hline \multirow[t]{8}{*}{ Mean $\pm S D$} & Age (years) & $73 \pm 10$ & $64 \pm 16$ \\
\hline & Intraocular pressure, IOP $(\mathrm{mmHg})$ & $13.2 \pm 2.9$ & $11.9 \pm 1.9$ \\
\hline & Cup disk ratio $(\mathrm{c} / \mathrm{d})$ & $0.72 \pm 0.16 / 0.70 \pm 0.16$ & PNM \\
\hline & right eye/left eye & & \\
\hline & Rim area $(\mathrm{RA})$ & $1.19 \pm 0.43 / 1.25 \pm 0.37$ & PNM \\
\hline & right eye/left eye & & \\
\hline & Retinal nerve fiber layer (RNFL) & $0.18 \pm 0.08 / 0.23 \pm 0.22$ & PNM \\
\hline & right eye/left eye & & \\
\hline
\end{tabular}

group without glaucoma symptoms (98 males and 90 females; mean age $64 \pm 14)$. All patients and controls were matched according to age (no difference was found, $\mathrm{p}>0.05$ ). All subjects underwent ophthalmologic examinations, including intraocular pressure (all patients had IOP $10-21 \mathrm{mmHg}$ - after drug therapy), best-corrected visual acuity, slit-lamp examination, gonioscopy and fundus examination using non-contact and contact fundus lenses with a slit lamp. Among the glaucomatous patients, the diagnosis of POAG was stated prior to enrolment, in accordance with the guidelines of the European Glaucoma Society (Terminology and Guidelines for Glaucoma, Second Edition, Dogma, Savona 2003, Italy).

Comprehensive medical history was obtained from each individual. Patients were not enrolled in the study if they suffered from any of the following conditions: use of any eye drops other than antiglaucoma preparations, present or past treatment with glucocorticosteroids or immunosuppressive therapy (if these treatments had not been stopped at least 1 year before collection of specimens), any ocular surgery or laser treatments performed in the past 6 months.

All subjects included in the study were unrelated Caucasians and inhabited Warsaw District, Poland. All patients were recruited from the Department of Ophthalmology, Medical University of Warsaw. The study was approved by the Committee for Bioethics of the Medical University of Lodz (Poland) and met the tenets of the Declaration of Helsinki. Written consent was obtained from each patient before participation in the study.

\section{DNA preparation and genotyping}

Blood samples were collected in $3 \mathrm{ml}$ EDTA tubes. Genomic DNA was isolated from peripheral lymphocytes using the kit QIAamp DNA and Blood Mini Kit (Qiagen, Chatsworth, CA, USA). The TP53 and GRIN2B genotypes were determined by polymerase chain reaction-restriction fragment length polymorphism (PCR-RFLP) according to previously described procedures with some modifications. Primer sequences used for the amplification are the same as described in previous publications [38, 39]. Each $20 \mu \mathrm{l}$ of reaction solution consisted of the following components: $10 \mathrm{ng}$ genomic DNA, $1.25 \mathrm{U}$ Taq polymerase (Qiagen, Chatsworth, CA, USA) in $1 \times \mathrm{PCR}$ buffer (100 mM Tris-HCl, pH 8.3; $500 \mathrm{mM} \mathrm{KCl}$; $11 \mathrm{mM} \mathrm{MgCl}_{2}, 0.1 \%$ gelatin), $1.5 \mathrm{mM} \mathrm{MgCl}_{2}, 50 \mu \mathrm{M}$ dNTPs and $250 \mathrm{nM}$ of each primer (Sigma-Aldrich, St. Louis, MO, USA). Thermal cycling conditions with primer sequences are presented in Table II. The PCR was carried out in a T100 thermal cycler (BioRad, Richmond, CA, USA).

To genotype the rs1042522 TP53 polymorphism ( $\mathrm{G} \rightarrow \mathrm{C}$ substitution) we obtained a 448 bp fragment, which was then treated with $B s t \mathrm{UI}$ enzyme (New England Biolabs, Ipswich, MA, USA) for 16 hours at $37^{\circ} \mathrm{C}$ with $1 \mathrm{U}$. The fragment of the TP53 gene containing the $\mathrm{G}$ variant was digested into 248 and $202 \mathrm{bp}$ fragments, while the $\mathrm{C}$ allele that lacks the restriction site remained uncut. To examine the GRIN2B -421C/A (rs3764028) polymorphism, the 115 bp PCR amplification product was then treated 
Table II. Primer sequences and restriction endonucleases used in the TP53 Arg72Pro and GRIN2B -421C/A gene polymorphism analysis by polymerase chain reaction-restriction fragment length polymorphism (PCR-RFLP)

\begin{tabular}{lrccc}
\hline Primer & Sequence & Annealing & Enzyme & Product \\
\hline TP53 Arg72Pro Forward & 5'-CCTGAAAACAACGTTCTGGTAA-3' & $56{ }^{\circ} \mathrm{C}$ & BstUI & 448 bp \\
TP53 Arg72Pro Reverse & 5'-GCATTGAAGTCTCATGGAAG-3' & & & \\
\hline GRIN2B -421C/A Forward & 5'-CGCTCTCCGTCGGTGCTGTT-3' & $61^{\circ} \mathrm{C}$ & HpyCH4IV & 115 bp \\
GRIN2B -421C/A Reverse & 5'-CTGGGGAAGTGGGGTGGTAACG-3' & & & \\
\hline
\end{tabular}

with $1 \mathrm{U}$ of $H p y C H 4 I V$ enzyme (New England Biolabs, Ipswich, MA, USA) for 16 hours at $37^{\circ} \mathrm{C}$. The wild-type $\mathrm{C}$ allele remained uncut, while the A allele was digested into 96 and 19 bp fragments. Restriction fragments were separated on an $3 \%$ agarose gel in a TAE buffer. The gel was stained with ethidium bromide and visualized under UV light.

To verify the correctness of the $B s t \mathrm{UI}$ and $H p y \mathrm{CHIV}$ enzymes' action, we used the pBR322 plasmid with a multiple cloning site containing 21 and 10 (respectively) restriction sites for these enzymes. Moreover, PCR products were previously sequenced to confirm the recognition site for the used restriction enzyme.

\section{Statistical analysis}

To compare the distributions of demographic variables and selected risk factors between patients and controls, the $\chi^{2}$ test was used. The observed number of cases for each genotype in the study and control group was compared with the expected number according to the Hardy-Weinberg principle, using the $\chi^{2}$ test. The $\chi^{2}$ analysis was also used to test the significance of the differences between distributions of genotypes in glaucoma patients and controls. The association between case-control status and each polymorphism, measured by the odds ratio (OR) and its corresponding $95 \%$ confidence interval (CI), was estimated using an unconditional multiple logistic regression model, both with and without adjustment for possible interfering factors. When calculating the probability, Pearson correction was used, and if the expected cell values were less than 5, Fisher's exact test was used. A p-value of less than 0.05 was considered statistically significant. Clinical features in patients with POAG were also compared between rs 1042522 and rs3764028 genotypes, by using an analysis of variance (ANOVA) for continuous variables and the $\chi^{2}$ test for a comparison of proportions. Statistical analysis was performed using STATISTICA 6.0 software (StatSoft, Tulsa, OK, USA).

\section{Results}

The genotype and allele frequency and odds ratios of the TP53 Arg72Pro and GRIN2B -421C/A polymorphisms in the study and control group are presented in Table III. The observed genotype frequen-

Table III. Genotype and allele frequencies and odds ratios (OR) of the TP53 Arg72Pro and the GRIN2B -421C/ A polymorphisms in POAG patients and controls

\begin{tabular}{|c|c|c|c|c|c|c|}
\hline $\begin{array}{l}\text { GENOTYPE } \\
\text { OR ALLELE }\end{array}$ & $\begin{array}{c}\text { POAG } \\
\text { PATIENTS } \\
\mathbf{N}=186\end{array}$ & $\begin{array}{l}\text { CONTROL } \\
\text { SUBJECTS } \\
\mathbf{N}=188\end{array}$ & $\begin{array}{c}\text { OR } \\
(95 \% \mathrm{CI})\end{array}$ & $P$ & $\begin{array}{l}\text { OR ADJUSTED }^{1} \\
(95 \% \mathrm{CI})\end{array}$ & $\mathrm{P}$ \\
\hline \multicolumn{7}{|l|}{ Arg72Pro } \\
\hline Arg/Arg & $104(56 \%)$ & $105(56 \%)$ & Ref. & Ref. & Ref. & Ref. \\
\hline Arg/Pro & $67(36 \%)$ & $72(38 \%)$ & $0.94(0.61-1.44)$ & 0.778 & $1.65(0.58-4.71)$ & 0.350 \\
\hline Pro/Pro & $15(8 \%)$ & $11(6 \%)$ & $1.38(0.60-3.14)$ & 0.446 & $0.61(0.21-1.73)$ & 0.350 \\
\hline Arg & $275(74 \%)$ & $282(75 \%)$ & Ref. & Ref. & Ref. & Ref. \\
\hline Pro & $97(26 \%)$ & $94(25 \%)$ & $1.06(0.76-1.47)$ & 0.740 & $1.34(0.90-1.98)$ & 0.147 \\
\hline \multicolumn{7}{|l|}{$-421 \mathrm{C} / \mathrm{A}$} \\
\hline $\mathrm{C} / \mathrm{C}$ & $170(91 \%)$ & $167(88 \%)$ & Ref. & Ref. & Ref. & Ref. \\
\hline $\mathrm{C} / \mathrm{A}$ & $15(8 \%)$ & $21(11 \%)$ & $1.43(0.71-2.86)$ & 0.317 & $1.39(0.60-3.21)$ & 0.439 \\
\hline $\mathrm{A} / \mathrm{A}$ & $1(1 \%)$ & $0(0 \%)$ & - & - & - & - \\
\hline C & $355(95 \%)$ & $355(94 \%)$ & Ref. & Ref. & Ref. & Ref. \\
\hline A & $17(5 \%)$ & $21(6 \%)$ & $0.81(0.42-1.56)$ & 0.527 & $1.04(0.77-1.40)$ & 0.793 \\
\hline
\end{tabular}


cies of TP53 (p >0.05; $\left.\chi^{2}=0.80\right)$ and GRIN2B $\left(\mathrm{p}>0.05 ; \chi^{2}=1.06\right)$ in the control groups were in agreement with Hardy-Weinberg equilibrium. Comparison of the distributions of genotypes and alleles of the Arg72Pro polymorphism of the TP53 gene as well as the $-421 \mathrm{C} / \mathrm{A}$ polymorphism of the GRIN2B gene and analysis of odds ratio (OR) showed no statistically significant differences between POAG patients and controls $(\mathrm{p}>0.05)$. The data show that TP53 and GRIN2B genes are not associated with hypertension, low blood pressure, vascular disease, diabetes or cancer according to the Arg72Pro and $-421 \mathrm{~A} / \mathrm{C}$ polymorphisms, respectively. Our data also did not establish an association of TP53 and GRIN2B com- bined genotypes with a risk of POAG in gene-gene interaction analysis ( $\mathrm{p}>0.05$; Table IV).

Analysis of the Arg72Pro of TP53 and -421A/C of GRIN2B gene polymorphisms depending on the clinical parameters in patients with primary open angle glaucoma for each eye counted are presented in Tables $\mathrm{V}$ and VI, respectively. There was no statistically significant association of the GRIN2B $-421 \mathrm{C} / \mathrm{A}$ polymorphism with progression of POAG depending on clinical parameters $(\mathrm{p}>0.05)$. However, there was a statistically significant association of the Arg72Pro polymorphism of the TP53 gene with progression of POAG depending on the retinal nerve fiber layer $(\mathrm{RNFL})(\mathrm{p}=0.019)$.

Table IV. Genotype and allele frequencies and odds ratios (OR) of combined genotypes of the TP53 Arg72Pro and GRIN2B -421C/A polymorphisms in POAG patients and controls

\begin{tabular}{|c|c|c|c|c|}
\hline $\begin{array}{l}\text { GENOTYPE } \\
\text { OR ALLELE }\end{array}$ & $\begin{array}{c}\text { POAG PATIENTS } \\
\mathrm{N}=186\end{array}$ & $\begin{array}{l}\text { Control SUBjeCts } \\
\quad \mathrm{N}=188 \\
\end{array}$ & $\begin{array}{c}\text { OR } \\
(95 \% \mathrm{CI})\end{array}$ & $P$ \\
\hline $\operatorname{Arg} / \operatorname{Arg}-\mathrm{C} / \mathrm{C}$ & $94(51 \%)$ & $90(48 \%)$ & Ref. & Ref. \\
\hline $\operatorname{Arg} / \operatorname{Arg}-\mathrm{C} / \mathrm{A}$ & $10(5 \%)$ & $15(8 \%)$ & $0.64(0.27-1.49)$ & 0.299 \\
\hline $\operatorname{Arg} / \operatorname{Arg}-\mathrm{A} / \mathrm{A}$ & $0(0 \%)$ & $0(0 \%)$ & - & - \\
\hline Arg/Pro - C/C & $62(33 \%)$ & $66(35 \%)$ & $0.90(0.57-1.41)$ & 0.647 \\
\hline Arg/Pro - C/A & $4(2 \%)$ & $6(3 \%)$ & $0.68(0.17-2.34)$ & $0.361^{\wedge}$ \\
\hline Arg/Pro - A/A & $1(1 \%)$ & $0(0 \%)$ & - & - \\
\hline Pro/Pro - C/C & $14(7 \%)$ & $11(6 \%)$ & $1.22(0.53-2.83)$ & 0.647 \\
\hline Pro/Pro - C/A & $1(1 \%)$ & $0(8 \%)$ & - & - \\
\hline Pro/Pro - A/A & $0(0 \%)$ & $0(0 \%)$ & - & - \\
\hline
\end{tabular}

Table V. Analysis of TP53 Arg72Pro gene polymorphism depending on the clinical parameters in patients with POAG for each eye counted

\begin{tabular}{|c|c|c|c|c|c|c|}
\hline $\begin{array}{l}\text { CLINICAL } \\
\text { PARAMETER }\end{array}$ & GENOTYPE & $\begin{array}{c}\text { POAG } \\
\text { PATIENTS }\end{array}$ & $\begin{array}{c}\text { QuARTILE } \\
25 \% \\
\end{array}$ & Median & $\begin{array}{c}\text { QuARTILE } \\
75 \%\end{array}$ & $P$ \\
\hline \multirow[t]{3}{*}{ GDx } & ARG/Arg & 111 & 17.0 & 25.0 & 51.5 & \multirow{3}{*}{0.431} \\
\hline & Arg/Pro & 64 & 13.5 & 23.0 & 42.0 & \\
\hline & Pro/Pro & 8 & 21.5 & 30.5 & 42.0 & \\
\hline \multirow[t]{3}{*}{$c / d$} & Arg/Arg & 201 & 0.60 & 0.74 & 0.80 & \multirow{3}{*}{0.434} \\
\hline & Arg/Pro & 130 & 0.60 & 0.75 & 0.85 & \\
\hline & Pro/Pro & 30 & 0.60 & 0.80 & 0.85 & \\
\hline \multirow[t]{3}{*}{ RA } & Arg/Arg & 165 & 0.97 & 1.28 & 1.48 & \multirow{3}{*}{0.316} \\
\hline & Arg/Pro & 87 & 0.92 & 1.24 & 1.44 & \\
\hline & Pro/Pro & 20 & 0.78 & 1.04 & 1.48 & \\
\hline \multirow[t]{3}{*}{ RNFL } & Arg/Arg & 165 & 0.12 & 0.18 & 0.24 & \multirow{3}{*}{0.019} \\
\hline & Arg/Pro & 87 & 0.14 & 0.21 & 0.26 & \\
\hline & Pro/Pro & 20 & 0.05 & 0.13 & 0.22 & \\
\hline
\end{tabular}


Table VI. Analysis of GRIN2B -421C/A gene polymorphism depending on the clinical parameters in patients with POAG for each eye counted

\begin{tabular}{|c|c|c|c|c|c|c|}
\hline $\begin{array}{l}\text { CLINICAL } \\
\text { PARAMETER }\end{array}$ & GENOTYPE & $\begin{array}{c}\text { POAG } \\
\text { PATIENTS }\end{array}$ & QuARTILE 25\% & Median & QuARTILE 75\% & $\mathbf{P}$ \\
\hline \multirow[t]{3}{*}{ GDx } & $\mathrm{G} / \mathrm{G}$ & 164 & 16.0 & 25.0 & 43.5 & \multirow{3}{*}{0.176} \\
\hline & $\mathrm{G} / \mathrm{A}$ & 17 & 19.5 & 27.0 & 69.0 & \\
\hline & $\mathrm{A} / \mathrm{A}$ & 2 & 2.00 & 12.5 & 23.0 & \\
\hline \multirow[t]{3}{*}{$\mathrm{c} / \mathrm{d}$} & $\mathrm{G} / \mathrm{G}$ & 330 & 0.60 & 0.75 & 0.82 & \multirow{3}{*}{0.147} \\
\hline & $\mathrm{G} / \mathrm{A}$ & 31 & 0.60 & 0.78 & 0.80 & \\
\hline & $\mathrm{A} / \mathrm{A}$ & 3 & 0.50 & 0.50 & 0.50 & \\
\hline \multirow[t]{3}{*}{$\mathrm{RA}$} & $\mathrm{G} / \mathrm{G}$ & 243 & 0.96 & 1.27 & 1.49 & \multirow{3}{*}{0.449} \\
\hline & $\mathrm{G} / \mathrm{A}$ & 27 & 0.86 & 1.14 & 1.43 & \\
\hline & $\mathrm{A} / \mathrm{A}$ & 2 & 1.33 & 1.34 & 1.35 & \\
\hline \multirow[t]{3}{*}{ RNFL } & $\mathrm{G} / \mathrm{G}$ & 243 & 0.12 & 0.18 & 0.25 & \multirow{3}{*}{0.267} \\
\hline & $\mathrm{G} / \mathrm{A}$ & 27 & 0.14 & 0.22 & 0.25 & \\
\hline & $\mathrm{A} / \mathrm{A}$ & 2 & 0.19 & 0.20 & 0.21 & \\
\hline
\end{tabular}

\section{Discussion}

Glaucoma is a neurodegenerative disease characterized by progressive damage of the optic nerve and retinal ganglion cells. It is considered that the development of glaucoma is determined by many factors, both environmental and genetic [40]. However, the pathogenetic factors leading to RGC death are not yet fully understood. Apoptosis is one of the hypotheses explaining the mechanism of neurodegeneration in glaucoma. Several studies have shown the histological and biochemical changes characteristic of apoptosis in RGCs, including internucleosomal DNA fragmentation and blebbing of plasma membrane $[15,16]$. The crucial protein regulating apoptosis is the transcription factor TP53. Mutations of the TP53 gene are present in a variety of tumors [41]. These changes lead to the production of a nonfunctional version of TP53 protein. The defective protein does not initiate the apoptotic process and, consequently, genetically damaged cells proliferate in an uncontrolled manner [42]. In turn, in neurodegenerative processes there is a substantial increase of TP53 expression, thereby promoting cell death through apoptosis $[43,44]$. These data suggest that functional genetic variants of the TP53 gene can affect the rate of neuronal cell loss in various neurodegenerative diseases, including glaucoma.

In our study, no significant differences were found between the genotype and the allele frequencies of the TP53 codon 72 polymorphism between POAG patients and control subjects $(\mathrm{p}>0.05)$. This result is confirmed by studies conducted in Indian, Turkish and Japanese populations [27, 28, 45], but some studies indicate a relationship of this polymorphism with the development of POAG [25, 26]. Lin et al. [26] demonstrated that the proline form of TP53 gene codon 72 appears to be a significant risk factor in the development of POAG $(\mathrm{OR}=2.39$ [95\% CI: 1.14-5.01, $\mathrm{p}=0.008]$ ). Moreover, studies performed in the U.S. population showed that the Pro/Pro genotype was more frequent in POAG patients with early visual field defects in the paracentral regions compared with those in the peripheral regions or the control group $(\mathrm{p}<0.001)$ [46]. In turn, Daugherty et al. revealed that subjects homozygous for the arginine allele had a significant 1.95fold higher risk of developing POAG than those who are heterozygous or lack the arginine allele $(95 \% \mathrm{CI}$ : $1.27-2.98, \mathrm{p}=0.002$ ) in a Caucasian population [25]. The discrepancy in the above results may be related to differences in ethnic populations in each study. According to the Hapmap data, the frequencies of the arginine and proline alleles in the Chinese population are 0.51 and 0.49 , respectively, while in the Caucasian population of European origin they are 0.77 and 0.23 , respectively. In our study, the allele frequencies among controls are similar to those from the Hapmap data. This polymorphism is located in a proline-rich domain, which is necessary for the protein to fully induce apoptosis. Some investigators showed that the Arg 72 variant induces apoptosis 15 times better than does the Pro72 variant [21]. They indicated that at least one source of this enhanced apoptotic potential is the greater ability of the $\operatorname{Arg} 72$ variant to localize to the mitochondria. This localization was accompanied by release of cytochrome $\mathrm{c}$ into the cytosol [21]. On the other hand, 
the study conducted by Thomas et al. showed that the $\operatorname{Arg} 72$ variant induces apoptosis with faster kinetics and suppresses transformation more efficiently than the Pro72 variant, but the Pro72 variant was a stronger inducer of transcription than the $\operatorname{Arg} 72$ variant [47]. Therefore, the finding of an association between increased risk of POAG and the polymorphic variant of the TP53 gene in various populations may be due to increased susceptibility of retinal ganglion cells to apoptosis.

We also studied the relationship between the polymorphism of the GRIN $2 B$ gene, encoding the NR2B subunit of the NMDA receptor, and the risk of POAG. However, no significant difference was observed regarding the GRIN2B genotype and allele frequencies at position $-421 \mathrm{C} / \mathrm{A}$ between the glaucoma patients and the control subjects $(\mathrm{p}>0.05)$. We could not compare our results with other studies because there is a lack of literature data on $-421 \mathrm{C} / \mathrm{A}$ GRIN2B gene polymorphism association with the risk of POAG. Similar cellular events, leading to nerve cell degeneration, are observed in both Alzheimer's disease (AD) and glaucoma. Jiang and Jia reported that there were significant differences in genotype $(\mathrm{p}=0.029)$ and allele $(\mathrm{p}=0.010)$ frequencies for the $-421 \mathrm{C} / \mathrm{A}$ polymorphism between $\mathrm{AD}$ and controls [38]. Using the luciferase assay they found that $-421 \mathrm{C}$ was associated with a $34.69-39.79 \%$ lower promoter activity than $-421 \mathrm{~A}$, which indicated that $-421 \mathrm{C}$ might reduce the transcriptional activity of GRIN2B and reduce NR2B expression. This is due to the fact that the $-421 \mathrm{~A} / \mathrm{C}$ polymorphism was located in one of the putative zinc finger protein ras-responsive element binding protein (RREB) binding sites [38]. Moreover, the RREB might be a negative transcription factor, and could down-regulate some genes' promoter activity and suppress their protein expression [48]. The NMDA receptor subunits are located on the inner retina of rodents, particularly at the RGCs. The studies using NMDA receptor antagonists have demonstrated that the loss of RGCs is attenuated in rodent and primate models of chronically elevated IOP and after optic nerve crush injury in rodents [33-35]. Therefore, changes in the NMDA receptor subunits may also play a crucial role in the pathogenesis of glaucoma.

Glaucoma has been defined by the three factors of increased intraocular pressure, optic disc damage and visual field defects. The $\mathrm{c} / \mathrm{d}$ ratio attempts to quantify the extent of axonal (nerve fiber) loss. It compares the diameter of the cup to the entire diameter of the optic nerve head (disc). In addition, loss of RGCs in glaucoma is the cause of visual field defects and thinning of the retinal nerve fiber layer (RNFL) [49]. Furthermore, rim area (RA) is clinically meaningful because the loss of RA tissue parallels the loss of RGCs [50]. There are many clinical parameters that describe the progressive changes in the optic nerve and visual field in glaucomatous patients. Our data present an association of Arg72Pro polymorphism of the TP53 gene with progression of POAG depending on the RNFL clinical parameter $(\mathrm{p}=0.019)$. A study revealed that the Pro72 variant increased apoptotic activity under hypoxic conditions [22]. Our data seem to be in agreement with these findings. We found that the Pro72 variant which is associated with apoptosis correlates positively with a decreased RNFL value (median: Arg/Arg 0.18 vs. Pro/Pro 0.13). This result perfectly fits the ischemic theory of glaucoma development, which is responsible for hypoxic conditions, and hence a decreased RNFL value may indicate progressive degradation of the optic nerve caused by apoptosis. These data may suggest the potential pathological role of the 72Pro variant in POAG. Confirmation of this relationship through a functional study is the goal of our current experiment. However, no significant differences were found between the $-421 \mathrm{C} / \mathrm{A}$ polymorphism of the GRIN2B gene and glaucoma progression depending on the clinical parameter $(\mathrm{p}>0.05)$.

In conclusion, our study revealed that TP53 and GRIN2B polymorphisms were not associated with risk of occurrence of POAG in the Polish population. However, the Arg72Pro polymorphism of the TP53 gene may be related to progression of POAG by its influence on RNFL decrease. Nevertheless, further studies with large numbers of patients and on other polymorphic variants in genes involved in the neurodegenerative mechanism are required to better understand the molecular basis of POAG and to find early diagnostic markers of POAG development.

The authors declare no conflicts of interest.

This work was supported by grant no. 2012/05/B/ NZ7/02502 and no. 503/5-108-05/503-01 from the Polish Ministry of Science and Higher Education.

\section{References}

1. Friedman DS, Wolfs RC, O'Colmain BJ, et al. Prevalence of open-angle glaucoma among adults in the United States. Arch Ophthalmol 2004; 122: 532-538.

2. Karna-Matyjaszek U, Sierzantowicz R, Mariak Z. Acceptance of own disease by patients with diagnosed glaucoma. Pol Merkur Lekarski 2010; 28: 37-41.

3. Quigley HA, Broman AT. The number of people with glaucoma worldwide in 2010 and 2020. Br J Ophthalmol 2006; 90: 262-267.

4. Mozaffarieh M, Grieshaber MC, Flammer J. Oxygen and blood flow: players in the pathogenesis of glaucoma. Mol Vis 2008; 14: 224-233.

5. Distelhorst JS, Hughes GM. Open-angle glaucoma. Am Fam Physician 2003; 67: 1937-1944.

6. Nickells RW. Apoptosis of retinal ganglion cells in glaucoma: an update of the molecular pathways involved in cell death. Surv Ophthalmol 1999; 43 Suppl 1: S151-S161. 
7. McKinnon SJ. Glaucoma, apoptosis, and neuroprotection. Curr Opin Ophthalmol 1997; 8: 28-37.

8. Garcia-Valenzuela E, Shareef S, Walsh J, et al. Programmed cell death of retinal ganglion cells during experimental glaucoma. Exp Eye Res 1995; 61: 33-44

9. Quigley HA, Guy J and Anderson DR, Blockade of rapid axonal transport. Effect of intraocular pressure elevation in primate optic nerve. Arch Ophthalmol 1979; 97: 525-531.

10. Dreyer EB, Zurakowski D, Schumer RA, et al. Elevated glutamate levels in the vitreous body of humans and monkeys with glaucoma. Arch Ophthalmol 1996; 114: 299-305.

11. Tezel G, Seigel GM, Wax MB, Autoantibodies to small heat shock proteins in glaucoma. Invest Ophthalmol Vis Sci 1998; 39: 2277-2787.

12. Osborne NN, Ugarte M, Chao M, et al. Neuroprotection in relation to retinal ischemia and relevance to glaucoma. Surv Ophthalmol 1999; 43 Suppl 1: S102-S128.

13. Yorio T, Krishnamoorthy R, Prasanna G. Endothelin: is it a contributor to glaucoma pathophysiology? J Glaucoma 2002; 11: 259-270

14. Mirabelli F, Salis A, Marinoni V, et al. Menadione-induced bleb formation in hepatocytes is associated with the oxidation of thiol groups in actin. Arch Biochem Biophys 1988; 264: 261269.

15. Mittag TW, Danias J, Pohorenec G, et al. Retinal damage after 3 to 4 months of elevated intraocular pressure in a rat glaucoma model. Invest Ophthalmol Vis Sci 2000; 41: 3451-3459.

16. Kerrigan LA, Zack DJ, Quigley HA, et al. TUNEL-positive ganglion cells in human primary open-angle glaucoma. Arch Ophthalmol 1997; 115: 1031-1035.

17. Levine AJ. p53, the cellular gatekeeper for growth and division. Cell 1997; 88: 323-331.

18. Levkovitch-Verbin H, Dardik R, Vander S, et al. Experimental glaucoma and optic nerve transection induce simultaneous upregulation of proapoptotic and prosurvival genes. Invest Ophthalmol Vis Sci 2006; 47: 2491-2497.

19. Li Y, Schlamp CL, Poulsen GL, et al. p53 regulates apoptotic retinal ganglion cell death induced by $\mathrm{N}$-methyl-D-aspartate. Mol Vis 2002; 8: 341-350.

20. Umihira J, Lindsey JD, Weinreb RN. Simultaneous expression of c-Jun and p53 in retinal ganglion cells of adult rat retinal slice cultures. Curr Eye Res 2002; 24: 147-159.

21. Dumont P, Leu JI, Della Pietra AC 3rd, et al. The codon 72 polymorphic variants of $\mathrm{p} 53$ have markedly different apoptotic potential. Nat Genet 2003; 33: 357-365.

22. Sansone P, Storci G, Pandolfi S, et al. The p53 codon 72 proline allele is endowed with enhanced cell-death inducing potential in cancer cells exposed to hypoxia. Br J Cancer 2007; 96: 1302-1308

23. Toffoli G, Biason P, Russo A, et al. Effect of TP53 Arg72Pro and MDM2 SNP309 polymorphisms on the risk of high-grade osteosarcoma development and survival. Clin Cancer Res 2009; 15: 3550-3556.

24. Fan BJ, Liu K, Wang DY, et al. Association of polymorphisms of tumor necrosis factor and tumor protein $\mathrm{p} 53$ with primary open-angle glaucoma. Invest Ophthalmol Vis Sci 2010; 51: 4110-4116.

25. Daugherty CL, Curtis H, Realini T, et al. Primary open angle glaucoma in a Caucasian population is associated with the $\mathrm{p} 53$ codon 72 polymorphism. Mol Vis 2009; 15: 1939-1944.

26. Lin HJ, Chen WC, Tsai FJ, et al. Distributions of p 53 codon 72 polymorphism in primary open angle glaucoma. $\mathrm{Br} \mathrm{J}$ Ophthalmol 2002; 86: 767-770.

27. Mabuchi F, Sakurada Y, Kashiwagi K, et al. Lack of association between $\mathrm{p} 53$ gene polymorphisms and primary open angle glaucoma in the Japanese population. Mol Vis 2009; 15: 1045-1049.
28. Acharya M, Mitra S, Mukhopadhyay A, et al. Distribution of p53 codon 72 polymorphism in Indian primary open angle glaucoma patients. Mol Vis 2002; 8: 367-371.

29. Bliss TV, Collingridge GL. A synaptic model of memory: longterm potentiation in the hippocampus. Nature 1993; 361: 31-39.

30. Kaul M, Garden GA, Lipton SA. Pathways to neuronal injury and apoptosis in HIV-associated dementia. Nature 2001; 410: 988-994.

31. Stephenson FA. Subunit characterization of NMDA receptors. Curr Drug Targets 2001; 2: 233-239.

32. Grunder T, Kohler K, Kaletta A, et al. The distribution and developmental regulation of NMDA receptor subunit proteins in the outer and inner retina of the rat. J Neurobiol 2000; 44: 333-342.

33. Chaudhary P, Ahmed F, Sharma SC. MK801 - a neuroprotectant in rat hypertensive eyes. Brain Res 1998; 792: 154-8.

34. Hare WA, WoldeMussie E, Lai RK, et al. Efficacy and safety of memantine treatment for reduction of changes associated with experimental glaucoma in monkey, I: Functional measures. Invest Ophthalmol Vis Sci 2004; 45: 2625-2639.

35. Yoles E, Muller S, Schwartz M. NMDA-receptor antagonist protects neurons from secondary degeneration after partial optic nerve crush. J Neurotrauma 1997; 14: 665-675.

36. Laube B, Hirai H, Sturgess M, et al. Molecular determinants of agonist discrimination by NMDA receptor subunits: analysis of the glutamate binding site on the NR2B subunit. Neuron 1997; 18: 493-503.

37. Zhao MG, Toyoda H, Lee YS, et al. Roles of NMDA NR2B subtype receptor in prefrontal long-term potentiation and contextual fear memory. Neuron 2005; 47: 859-872.

38. Jiang HQ, Jia JP. Association between NR2B subunit gene (GRIN2B) promoter polymorphisms and sporadic Alzheimer's disease in the North Chinese population. Neurosci Lett 2009; 450: 356-360.

39. Ressiniotis T, Griffiths PG, Birch M, et al. Primary open angle glaucoma is associated with a specific $\mathrm{p} 53$ gene haplotype. J Med Genet 2004; 41: 296-298.

40. Fuse N. Genetic bases for glaucoma. Tohoku J Exp Med 2010; 221: 1-10.

41. Hainaut P, Soussi T, Shomer B, et al. Database of p53 gene somatic mutations in human tumors and cell lines: updated compilation and future prospects. Nucleic Acids Res 1997; 25 : 151-157.

42. Sekido Y, Fong KM, Minna JD. Molecular genetics of lung cancer. Annu Rev Med 2003; 54: 73-87.

43. Shahbazian MD, Orr HT, Zoghbi HY, Reduction of Purkinje cell pathology in SCA 1 transgenic mice by $\mathrm{p} 53$ deletion. Neurobiol Dis 2001; 8: 974-981.

44. LaFerla FM, Hall CK, Ngo L, et al. Extracellular deposition of beta-amyloid upon p53-dependent neuronal cell death in transgenic mice. J Clin Invest 1996; 98: 1626-1632.

45. Saglar E, Yucel D, Bozkurt B, et al. Association of polymorphisms in APOE, p53, and p21 with primary open-angle glaucoma in Turkish patients. Mol Vis 2009; 15: 1270-1276.

46. Wiggs JL, Hewitt AW, Fan BJ, et al. The p53 codon 72 PRO/ PRO genotype may be associated with initial central visual field defects in caucasians with primary open angle glaucoma. PLoS One 2012; 7: e45613.

47. Thomas M, Kalita A, Labrecque S, et al. Two polymorphic variants of wild-type p53 differ biochemically and biologically. Mol Cell Biol 1999; 19: 1092-1100.

48. Zhang S, Qian X, Redman C, et al. p16 INK4a gene promoter variation and differential binding of a repressor, the ras-responsive zinc-finger transcription factor, RREB. Oncogene 2003; 22: $2285-2295$. 
49. Harwerth RS, Vilupuru AS, Rangaswamy NV, et al. The relationship between nerve fiber layer and perimetry measurements. Invest Ophthalmol Vis Sci 2007; 48: 763-773.

50. Owen VM, Strouthidis NG, Garway-Heath DF, et al. Measurement variability in Heidelberg Retina Tomograph imaging of neuroretinal rim area. Invest Ophthalmol Vis Sci 2006; 47: 5322-5330.

\section{Address for correspondence}

Ireneusz Majsterek

Department of Clinical Chemistry and Biochemistry

Medical University of Lodz

Hallera 1 Square

90-647 Lodz, Poland

e-mail: ireneusz.majsterek@umed.lodz.pl 